Original Research Paper

\title{
The Reality of Palestinian Prisoners in Israeli Jails: Haytham Jaber's Novel "The Captive" as a Model
}

\author{
Dr. Amal Abu Hanish \\ Faculty of Humanities, Arabic Department, An-Najah National University, Palestine
}

Article history

Received: 9-05-2018

Revised: 28-08-2018

Accepted: 24-09-2018

Email: amal-abu-

hanesh@hotmail.com

\begin{abstract}
The theme of prisons, torture and absence of freedoms is part of the discourse of the Palestinian narrative, specifically those written by the Palestinian prisoners in Israeli jails, making prison descriptions and the colors of torture and humiliation both enjoyable and disturbing. There is a precise description of the violence and brutality of torturers in the cells of prisons and interrogation centers. The main purpose of this research is examine and analyze Haytham Jaber's novel "The Captive" in order to find out and shed light on the reality of Palestinian prisoners in the prisons of the Israeli occupation and the way they manage their life including daily routines, politics and struggle against their jailors in addition to the ugly image of the prison and prisons. The study findings show that, despite the weakness of its linguistic structures and complexity and the large number of spelling and typographical mistakes, the novel is still an important addition to the prison literature for its detailed information about the lives of Palestinian prisoners in Israeli jails.
\end{abstract}

Keywords: Haytham Jaber, Israeli Jails, Palestinian Captivity Movement,

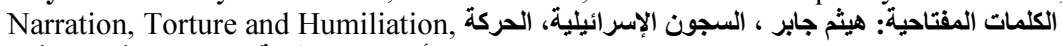
الأسيرة الفلسطينية، السرد، التعذيب والإذلال

\section{Introduction}

\section{The Literature of Prisons}

The political and social conditions experienced by the Palestinian people have turned into a sharp turning point in the history of the Palestinian people and in its literary and prose productions alike. Literature has become one of the most important means of struggle, especially those produced by the Palestinian prisoners in Israeli jails.

The literature of prisons has an extension in the history of Palestinian literature and the history of Arabic and international literature as well. There is a number of writers and novelists: Arabs and international who contributed outstandingly in this genre and documented prisoners' experience in jails in poetry and prose. However, the creative writing of Palestinian prisoners in Israeli prisons remains the most comprehensive, in terms of quantity and quality, among the experiences of other peoples and liberation movements, because of its connection to the Palestinian cause and the nature of the Israeli occupation, which is the longest in history ${ }^{1}$ (Abdullah,H. 1994).

${ }^{1}$ Look at Abdullah, H. (1994): An-Nitajat Al-Adabiya AlI'ietiqaliya: Dirasah Tarikhiya Tahliliya (Captivity Literary
The literature of Palestinian prisons is a seen as a literary phenomenon that has imposed itself on modern Palestinian literature. Al-Salhout (2012) maintains that this phenomenon began with Khalil Beidis in the early 20th century during the British Mandate, when he recorded his experiences in the Mandate prisons in a book entitled "Prison Literature ${ }^{2}$." Furthermore, Mahmoud Darwish, Samih al-Qasim and Tawfiq Ziad wrote some of their poems inside the prisons of the Israeli occupation. Mu'in Bseiso described his experience in Egyptian prisons and in a book entitled "Dafater Falastinniya"." Translated as (Palestinian Notebooks)" (Ziyyad,M.2006).

The literature of the Palestinian prisons, which was formed in an atmosphere of oppression and suppression, has gone through several stages that have led to its refinement and proved its presence and spread in the Palestinian literary scene. It has been considered as a

Products: A Historical-analytical study). Jerusalem: Al-Zahra'a Studies and Research Centre, Palestine.

${ }^{2}$ For more details, look at Salhout, J. (2012): Adab As-Sojoun (Prison Literature). Jerusalem: Dar Al-Jundi, Palestine.

${ }^{3}$ Look at Ziyaad, M. (2006): Al-Adab Al-Filistini fi sojoun AlIhtilal 1987-2000 (Literature Produced by Palestinian Prisoners in Israeli Jails 1987-2000). Unpublisshed Master's thesis, Beir Zeit University, Beir Zeit, Palestine. 
vivid and realistic picture of their struggle and suffering in the interrogation cellars and prisons of the Israeli occupation. The early beginnings of prison literature came in poetry due to the fact that poetry is the most influential way to express feelings, emotions and sufferings. In 1975, the first verses of this kind came from Beersheba prison; a number of Palestinian prisoner writers and poets came up with a joint handwritten collection of poems entitled "كلمات سجينة translated as (Imprisoned Words). In the 1980s, the of creativity of imprisoned intellectuals and academics who were arrested during the first Intifada had developed significantly; most of them have played an important role in directing the imprisoned writers, poets and novelists to the mechanisms and rules of the artistic writing of literature. During this period, they managed to smuggle their creative production out of Israeli prisons and detention centers. Palestinian newspapers, magazines and local publishing houses were interested in publishing their production, encouraging them to continue writing so that they develop their creations which culminated in producing and publishing a number of novels.

During the post-Oslo era and after the advent of the Palestinian Authority and the Al-Aqsa Intifada - the second intifada - have all witnessed a significant amount of prison literature: prose and poetry; many free prisoners have published several poetic and prose writings. For example, Aisha Awda, wrote her own biographies entitled "translated as (Dreams of Freedom) and "ثمنا للشمس" translated as (For the Sake of Sun). Another Palestinian writer, Al-Mutawakkil Taha, wrote a novel entitled " رمل الأفعى- سبرة كتسيعوت ـ أو الو 3 translated as (The Snake's Sand- Memoirs of Katsiot, Ansar 3 Detention Camp). Another famous Palestinian prisoner writer is Walid Houdali; he published a novel "ستائر العتمة" (Curtains of Darkness). A number of prisoners are still detained in the prisons of the occupation including Kameel Abu Hanish, who is sentenced to nine life imprisonment, wrote two novels called "بنشائر" (Good Tidings) and "وجع بلا قرار" ( Endless Pain). Basem Khandakji, who is sentenced to three life imprisonment, published a novel entitled مسك الكفايةسبيرة سيدة translated as (The Good Ending ${ }^{4}$ )(Al-

${ }^{4}$ For more details, see Odeh, A. ( 2005): Ahlam Bil-Huriya (Dreams of Freedom). Beirut: Arab Institute for Research and Publishing; Odeh, A. ( 2012): Thaman LeshShams (For the Sake of the Sun). Palestine: Democracy; Taha, M. (2010): Raml Al-Afaa -Sirat Ktsiot- Or Ansar 3 (The Snake's Sand --Memoirs of Katsiot, Ansar 3 Detention Camp). Cairo: General Organization of Culture Palaces; Al-Hodaly, W. (2003): Sataer Al-Atmah: Tisoun Yawman fi Zanazeen AsSojoun Al-Israeliya (Curtains of Darkness: Ninety Days in Israeli Prison Cells). Ramallah, Palestine: Palestine Institution for National Guidance; Abu Hanish, K (N.D.): Bashaer (Good Tidings). Ramallah: Palestinian National Committee for
Hodaly;2003,Odeh,A. 2005;Odeh,A 2012; Taha, 2010Abu Hanish,K.2017).

In this purely descriptive, interpretive study, the researcher seeks to shed light on the world and reality of Palestinian prisoners in Israeli jails in order to reveal the way they manage their life and political affairs and to highlight the image of prison and jailors as shown in the novel "The Captive" written by Haytham Jaber ${ }^{6}$.

\section{Research Methodology}

This study is based on a qualitative, descriptive and interpretative approach to identify the world of Palestinian prisoners in Israeli jails; it aims at analyzing the novel "Prisoner" written by a Palestinian writer called Haitham Jaber, while serving a twenty-eight-year sentence in the Israeli jails. The author intends to investigate a number of issues related to the life of prisoners such as (The sleep, the food, the rush, the visit, the reception of the new prisoners ...) and answer some related questions including (Is there any sort of cultural and educational life inside the prison and who are those that are responsible for it? How do prisoners manage their political life and struggle within the prison? Is there a leadership for the prisoners inside the prison, how are they chosen and what are the tasks they are doing? What forms of struggle the prisoners have within the prison and what are the causes and objectives of this struggle? What is the picture that the novel portrayed to the Israeli prison and jailor? How are detainees arrested and interrogated? Can the novel reflect the reality of the Palestinian prisoners and their suffering in the prisons of the occupation?

Furthermore, the researcher reported a number of studies that dealt with the subject of Palestinian prisoners in Israeli jails, or their literature, such as: The democratic experience of the Palestinian prisoners in the Israeli prisons (1967-2007) for Muhannad Hussein al-Hajj. And the literary productions of the detention, for Hassan

Education, Culture and Sciences; Abu Hanish, K. (2017): Alam bela qarar (Endless Pain). Nablus:People's Library; Khandakji, B. (2014): Misk Al-Kifaya "Sirat Sayed Al-Zilal Al-Hura"(The Good Ending). Beirut: Arab Scientifc Publishers.

${ }^{5}$ Jaber, H. (2016): Al-Aseer (The Captive). Nablus: People's Library, Palestine.

${ }^{6}$ Haytham Jaber is a Palestinian prisoner who was born in 1974 comes from the town of Haris, near the city of Salfit; he was arrested in 2002 at An-Najah National University on charges of belonging to the Al-Quds Brigades, the military wing of the Islamic Jihad and participating in the Saraya operations against the occupation. He was sentenced to 28 years in prison where he joined Al-Aqsa University and graduated from the History Department. Among his writings are "Loopholes in love and war" and the novel of "The She Martyr". 
Abdullah. And the Palestinian literature in the prisons of the occupation, to Mahmoud Ziad.

\section{The Structure and Theme of the Novel}

Haytham Jabir identifies his literary text, which is located in (223 pages) of the average pieces. The cover shows the title of the novel that is divided into sections; each section carries a number that tells about the suffering of the Palestinian prisoner inside the walls of the Israeli jails; the number also shows the prisoners' steadfastness and the management of their life as well as the ugly image of the Israeli jailor through the story of the protagonist of his novel, a Palestinian youth and a university student, he was imprisoned on charges of resisting the occupation. In prison, the occupier exercised all forms of oppression and suppression.

The novel "The Captive" seems to be a narrative novel far from illusion and fantasy. It is the product of severe and painful psychological and physical suffering for the author and hero of his novel and for other Palestinian prisoners in general. This is why the protagonist and the various characters came without specific names or special features that define their own qualities just as the title of the novel itself which seems bare and without any specific meaning as if the author wants to inform his readership that the story of the prisoner in his novel is only the story of other young Palestinians who have become mere figures or numbers who do not differ from each other in the prisons of the occupation.

In the novel, the prison represents the spatial focus through which the author tries to shed light on the lives and realities of the Palestinian prisoners, to determine for future generations, the various ways to try and absorb the life of the prison which is based on the foundations imposed by the cruelty of imprisonment and the oppression of the jailer because literature itself, as Shukri (1970) puts it, is a human activity that resists the different factors of weakness and feebleness that strike the human soul at moments of refraction ${ }^{7}$.

The narration in this novel is carried out by a special kind of narrator; he is a knowledgeable partisan without specific qualities or distinctive features. He shares a number of personalities and leading figures in the narration of the events. The voices and sounds of the narrator and the characters are mixed and work cooperatively- via different narrative techniques including dialogues, messages and using various forms of narrative pronouns- to portray the lives of the Palestinians not only inside the prison but also outside of it. The dialogue overshadows all other techniques. The external dialogue between the new prisoner and the old

\footnotetext{
${ }^{7}$ See Shukri, G. (1970): Adab Al-Muqawamah (Resistance Literature).Cairo: Dar Al-Maarif, Egypt. page 7.
}

prisoner is used as a means to draw a solid picture of the struggle and steadfastness of the prisoner movement and the way of managing its life including the organizational affairs in the prisons of the occupation. The prisoners use a simple language that is close to the reality it expresses; however, it sometimes tends, in its structures, to feebleness and stagnation. For instance, the narrator says " He (the prisoner) was sitting with one of his brothers on the bed ..." The internal dialogue (Monologue) comes to reveal what is going on inside the hero of the novel in terms of ideas, dreams, feelings and emotions, in a slender poetic language that is more to traditional poetry than to prose such as "He was asking himself whether he deserves to love or not. The answer comes from inside his thoughts and wonders saying: it is only the rebels who pull the trigger are capable of picking flowers from the crimson cheeks ${ }^{9} "$. While the messages and letters, between the prisoners and their families, are used to express the steadfastness of the Palestinian prisoner, specifically with their lovers; these letters help them gain the strength and the power to endure and bear the troublesome and miserable life inside the prison; furthermore, the letters help ruin and fail the occupation plans to isolate the prisoners from their families and society and cut off communication with them. In one of the klletters he says: " My Madam is the lady of words; she is my poetry inspiration and source of my sadness. Yoday I stand in from of your eyes carrying hopes and the reality of being imprisoned for life and being always running away to the unknown. ${ }^{10 "}$

\section{The Way Prisoners Manage their Life}

Haytham Jaber takes the readership to a journey in the world of prisoners inside the prisons that are run by a nasty Zionist occupation sometimes through narration and sometimes through dialogue. The author tries to build a world parallel to the real world to monitor and portray everything that surrounds the prisoners and to highlight bright aspects of their political, organizational and struggle experience in an attempt to strengthen the steadfastness of the Palestinians inside and outside prisons. The prisoners have paid a heavy price to obtain their minimum human rights in prisons so that they could maintain their individual and collective self. They are depicted, by Abu Salamah, as free people despite being behind the bars of the jails who describes them when he addressed the resistance poets in the occupation

${ }^{8}$ Jaber, H. (2016): Al-Aseer (The Captive). Nablus: People's Library, Palestine. Page 53.

${ }^{9}$ Jaber, H. (2016). Al-Aseer (The Captive). Nablus: People's Library, Palestine. Page 51.

${ }^{10}$ Jaber, H. (2016): Al-Aseer (The Captive). Nablus: People's Library, Palestine. Page 198. 
camps: "We (poets) are prisoners and you (prisoners) are free from prison and bars. ${ }^{11 "}$ (Al-Karmi, 1971).

\section{Leading the Captives}

"The Captive" also goes around a major theme that relates to the experience of the Palestinian prisoners in the trip of survival amidst the ruins and deaths within the confinements of Israeli jails. They exert whatever effort they have to face the occupier's insistence on turning them into victims. In prison, an elected administrative committee of prisoners is composed; it consists of a president, assistants and delegates that are divided into different sections and assigned roles according to the various wards of the prison. This committee supervises the lives of the prisoners including hours of sleep, waking and time of food in accordance with all the moods and passions. In other words, the committee organizes the dayto-day life that begins with the morning count, the sports hour, the break, the breakfast, the first cultural session, the noon prayer and the siesta, the evening break and other daily activities. The committee also appoints public service workers who serve their imprisoned brothers inside the prison and supervise their work in the laundry, the library, the kitchen and others ${ }^{12}$.

\section{Reception of New Prisoners}

Haytham Jaber stresses, in his novel, the way the old prisoners receive and hold their fellow new prisoners. The new prisoner is cordially received in an orientation party that is held by all Palestinian factions and brigades inside the prison; each person is willing to participate so as to get to know him and introduce himself to everyone. In this context, the protagonist of the novel tells us, based on his own experience in captivity, about the attention and care he and other new prisoners who had no previous experience in captivity have gained so that they get used to prison life and learn about its laws. These parties, according to Abu al-Haaj (2016), are normally followed by other sessions to provide new comers with the necessary information about life in prison due to the lack of sufficient information and studies on the lives of prisoners inside Israeli prisons ${ }^{13}$.

\section{Education and Culture}

Through this narration and dialogue, we learn about the art of survival in the midst of ruin and death and how prisoners managed to break the cultural siege imposed

\footnotetext{
${ }^{11}$ Al-Karmi, A. (1971): Min Filastin Rishati (From Palestine is My Brush). Beirut: Dar

Al-Adaab, Lebanon.

${ }^{12}$ Jaber, H. (2016). Al-Aseer (The Captive). Nablus: People's Library. Page 56.

${ }^{13}$ Jaber, H. (2016): Al-Aseer (The Captive). Nablus: People's Library, Palestine. Pages 47; 53.
}

on them and improve their detention ${ }^{14}$. Inside their cells, prisoners are kept on educational and cultural programs, supervised by a cultural committee headed by a general supervisor; this committee arranges educational and cultural plans for all the prisoners, supervises the cultural programs for each faction or party aside, organizes cultural sessions throughout the day in different prison wards, assigns organizational cadres and university students superior tasks to teach their fellow prisoners and chair dialogue sessions and forums in the various political, religious and dynamic issues for each Palestinian faction, each according to its intellectual ideology and political beliefs based on their contention that science and culture give the prisoner strong will and patience to challenge and confront all hardships and sufferings.

\section{Prisoners' Financial and Economic Matters}

We are informed by Haytham Jaber about what the old prisoner, the protagonist, tells of his story about how the prisoners manage their financial and economic affairs inside the prison, the role of the financial committee in supervising the canteen and providing financial support to the prisoners to enable them to purchase their individual needs equally without any distinction between the rich and the poor. In the prison, individual property is lost and the collective ownership of equality prevails among them. This experience becomes an incentive for the formulation of a real democratic life outside the walls of the prison and for generations to benefit from. The narrator says: "Now it is time for the financial committee which is responsible for getting money from outside the prison and managing it so that everyone gets his share regardless of his political affiliation ${ }^{15}$ or whether he is rich or poor. ${ }^{16 "}$ This quotation demolishes the financial barrier between prisoners and replaces individual ownership with collective one. Such a behavior promotes democracy and pushes prisoners to make use of it not only inside the jail but also outside of when they get released.

\section{Month of "Ramadan" and the "Eid"}

The readership of "The Captive" is very likely to read about the human and social dimension along with the national and cultural dimensions. The best example of this is the narration of the rituals of Ramadan and Eid in

\footnotetext{
${ }^{14}$ For more details about the captives' struggle for their right of education inside prisons see: Abu Al-Haaj, M. (2016): AtTajriba Ad-Dimoqratiya Lel-Asra Al-Falestinineen fi AlMuataqlat Al-Israeliya 1967-2007 (The Democratic Experience of Palestinian Prisoners in Israeli jails 1967-2007). Al-Quds University: Abu Jihad Centre for Prisoners' Affairs, Palestine. Pages 124-129.

${ }^{15}$ Jaber, H. (2016): Al-Aseer (The Captive). Nablus: People's Library, Palestine. Page 56.

${ }^{16}$ Ibid page 59.
} 
the prison as well as the prisoners' attempts to capture the moments of life from the pangs of death; the prisoners try constantly to make the joy of this month and to live in the atmosphere of Eid despite their torment, plight and lack of warmth of the Family and their beloved people.

In Ramadan, the National Committee supervises the affairs of the prisoners. It issues a circular to extend congratulations and directives that affirm the inviolability of the month of Ramadan, the need to stay away from all that harms the reality of the detention. The circulations also clarify the new programs of breaks and the matters agreed upon with the prison administration regarding their demands during this month. On their side, the prisoners set up a special program that provides them with an atmosphere of reverence and spirituality to enable each prisoner to perform his religious duties, such as turning off the television and replacing religious programs with entertainment ones.

In the Eid, the prisoners try to preserve the rituals of the occasion and restore the joy that was robbed of them. Feeling joy is part of the resistance and it angers the jailor who wants to empty and deprive them of their human content and value via switching the TV early ${ }^{17}$, banning watching recreational programs and doing some fun activities. Therefore, the prisoners insist on cleaning and tidying their rooms and making sweets from the remains of dry bread. In the morning of the Eid, the prisoners prepare the courtyard for Eid Prayer after the morning count, which begins early and visit each other in their rooms to extend congratulations and exchange greetings ${ }^{18}$.

\section{The Tragedy of Death}

As the story goes on, we learn about what the old prisoner says about the tragedy of death inside the prison, the feelings of grief and suffering of the inflicted prisoner, the way the prisoners' handle and live this tragedy and how they manage the house of mourning, by recounting the story of one of the prisoners who learned of his mother's death a week after her death while reading a newspaper ${ }^{19}$.

Inside the jail, the prisoners practice special rituals. They normally start when the representative of the ward asks for permission from the prison administration to allow the prisoners to build a house of condolence to support the inflicted prisoner. The last hour of the break is assigned for this; black coffee is made and the senior prisoners and the elderly take the condolence and receive solace. In the house of condolence which is erected in

\footnotetext{
${ }^{17}$ Ibid page 137 .

${ }^{18}$ Ibid pages $145,146$.

${ }^{19}$ Ibid page 168.
}

the courtyard of the prison, a sermon about patience and endurance is delivered. Inside the rooms, where the prisoners usually share their joys and sorrows, everyone keeps away from watching the comic and lyrical programs and sadness appears on their faces ${ }^{20}$.

\section{Managing and Organization and Political Affairs}

\section{The Democratic Experience of Prisoners}

"The Captive" is among the few novels that have considered the topic of prisoners and the way they manage their organizational and democratic affairs inside the Israeli jails. The novel uses a narrative technique that is similar to demonstrative realism for the sake of teaching and informing the prisoners about different matters including the reality of prison life and the way to deal with imprisonment. This makes the novel a typical novel ${ }^{21}$. The writers' use of the narrative technique in this type of prison novels is a plus to this genre rather than a disadvantage ${ }^{22}$.

Haytham Jaber presents his readership-via a narrative dialogue between the hero of his novel and one of the veteran prisoners who spent years in Israeli jails- with a shining picture of the Palestinian prisoners' democratic experience of handling power within the prison (Abu alHaaj, 2016). This should be an incentive to shape a democratic life for those outside its walls who are supposed to fully follow it. He tells about the way they elect their leaders and representatives who are supposed to manage affairs as well as their internal constitution, which regulates the relationship of the prisoners with each other and with their families during visits; they also manage the relationship of each faction with its members and with other factions or organizations. They constantly do these things in order to the establishment of detention facilities, detailed internal regulations that cover their daily lives and hierarchical organizational structure. In the prison, an elected leadership body representing all the Palestinian factions is formed within its cells; it is called the national public body. It shall assume its responsibilities and duties in the leadership of the captive movement through the committees and bodies emanating from $\mathrm{it}^{23}$.

\footnotetext{
${ }^{20}$ Ibid page 168 .

${ }^{21}$ For more information about the concept of traditional novel, see Madi, Sh. (2008): Modern types of Arabic Novel. Kuwait: Alam A-Marefah, Kuwait.

${ }^{22}$ See, Al-Natsheh, J. I. J (2016): The Palestinian captive as a narrator. Unpublished doctoral dissertation. Jordan University, Amman, Jordan.

${ }^{23}$ For more information about this topic see, Abu Al-Haaj, M. (2016): At-Tajriba Ad-Dimoqratiya Lel-Asra Al-Falestinineen fi Al-Muataqlat Al-Israeliya 1967-2007 (The Democratic Experience of Palestinian Prisoners in Israeli jails 1967-2007).
} 
In a quasi-documentary technique that spoils the novel in many aspects, the reader gets to know, through the old prisoner and his position at the heart of the event, how the prisoners elect the committees of that represent the factions and political parties inside the prison ${ }^{24}$. Each political faction/organization has an organizational committee consisting of (6-7) individuals, headed by a general supervisor or a secretary who is normally the highest authority in the organization ${ }^{25}$. This person is elected by direct election according to the electoral laws of each organization and this committee will continue its work for six months until another new committee is reelected. Furthermore, the reader of this novel is also introduced to the formation of many committees inside the prison and the tasks entrusted to them including the administrative, the cultural and the financial committee. The author also introduces the representative of the prisoners and his role in coordinating the factions, speaking on behalf of prisoners of different political orientations and following up their problems and demands from the prison administration ${ }^{26}$.

\section{Struggle and Resistance Inside the Prison}

Haytham Jabir paints, in his novel, an accurate picture of the suffering of the Palestinian prisoner in various aspects through a quasi-documentary narrative dialogue that revolves around any new prisoner and one who has already spent years in Israeli jails. The narrative of the documentary focuses on the struggle of the captive movement and its beginnings in Israeli jails ${ }^{27}$. We read about the first strike that Palestinian prisoners held to be recognized as prisoners of war in 1970 and of other strikes through a detailed account of their causes and objectives, how to plan them, the tactical steps that precede their declaration and those responsible for their follow-up. We also read about the 1976 strike, which lasted for more than 65 days, to demand the entry of books, stationery and newspapers, the abolition of the fact that prisoners are to put their hands behind their back during the count and to direct their faces to the wall. The author also talks about the 1980 hunger strike which began in Nafha Prison near the Negev Desert and lasted for 33 days. The Palestinian prisoners demand brushes to clean and duct the rooms; the Israeli Prison Services should remove the iron panels that cover the windows and prevent sunlight from entering the rooms; and that they should allow the introduction of television and radio. In this narrative, we read about the killing of Ali al-Ja'abari and Basem Halawa as a result of the

Al-Quds University: Abu Jihad Centre for Prisoners' Affairs, Palestine.

${ }^{24} J a b e r, ~ H . ~(2016)$ : Al-Aseer (The Captive). Nablus: People's Library, Palestine. Page 58.

${ }^{25}$ Ibid page 58 .

${ }^{26}$ Ibid page 59 .

${ }^{27}$ Ibid page 119. prison administration's attempt to feed them through catheters. The author also informs his readership about the the prisoner's day that is commemorated in honor of the two martyrs and other martyrs of the prisoner movement ${ }^{28}$. The 1984 Junied Prison, near Nablus, hunger strike that lasted for several days until the demands- the introduction of television and newspapers and improving the quality of food in quantity and quality- of the prisoners were met is also mentioned in details in the novel ${ }^{29}$. The 1985 strike which lasted for 10 days was initiated in order to prevent the prisoner from spraying the prisoners with tear gas as a punitive measure and in response to the prison administration's disavowal of its promises and commitments after the release of most of their leaders in the famous prisoners' exchange deal between the Popular Front for the Liberation of Palestine and Israel that year. We also read about the 21-day 1987 strike to restore all the achievements and privileges of the prisoners and the 1992 strike, in which the prisoners demanded the release of those who were isolated in solitary confinement, the closure of cells lacking human life conditions, allowing them to purchase foodstuffs from the canteen and bringing fans and blankets into the rooms. This strike continued until their demands were approved. In the same context we read about other strikes by the captive movement to demand the release of prisoners ${ }^{30}$.

\section{Hunger Strikes Management}

In the context of the account of the prisoners about the struggle of the captive movement, the old prisoner narrator gives us detailed information about the reasons for the hunger strikes in the prisons of the occupation, its objectives, how to plan, announce and follow them and the Israeli Prison Service's reaction to them. The old prisoner says "Now I'll tell you more about the strike and everything related to it, but you've to know that it's their last option after exhausting the means of dialogue with the prison administration and their rejection of their demands. When we present all our demands to the prison administration and after try all other dialogue options, we start tactical measures until we are pushed to strikes $^{31}$. The hunger strike is a means of fighting the jailors to improve the conditions of their detention and preserve their dignity."

The announcement of the strike is preceded by tactical steps such as returning a meal of food every day in the first week, then returning the food for two or three days of the second week and boycotting the clinic and canteen. The general and comprehensive strike is decided by the leadership of the captive movement after studying the

\footnotetext{
${ }^{28}$ Ibid page 119 .

${ }^{29}$ Ibid page 121.

${ }^{30}$ Ibid page 123 .

${ }^{31}$ Ibid page 96.
} 
political and objective conditions experienced by the region and the Palestinian arena and following a referendum among the prisoners by voting on the resolution.

The practical preparation of the strike begins with the drafting of a national circular with the announcement of the strike drawn up by the national and Islamic factions inside the prison ${ }^{32}$. It is passed between the various prison cells. Each chamber director manages the discussion on the issues he holds and the demands of the captive movement. The National Committee for Mobilization and Guidance monitors the strike. The old prisoner says "It directs the prisoners to how they should behave during the strike and reveals the prison administration's rumors about the dangers of the strike and the diseases they cause in order to reduce the prisoners' resolve or decision and dissuade them from continuing the strike ${ }^{33 "}$.

In order to effectively follow up the strike, shadow committees are formed to replace the strike leaders if they are transferred to other prisons without giving them the authority to talk to the prison administration about strike matters. "These committees are headed by a highranking committee composed of all the Palestinian factions within the captive movement". They are often the leaders of the factions and they are the only ones who have the right to continue the strike or finish it if the demands of the prisoners are met or the minimum is met $^{34}$.

In this context, the readership learns about the steps taken by the prison administration to confront the strike sometime through narration and sometimes through dialogue. The first step is to declare a state of emergency in prisons, abolish police leaves, impose a permanent presence of the prison staff, form special committees of security experts and psychologists to study the prisoners' psychology and find gaps in which they can thwart the strike. In the field, the soldiers and the prison guards break into the various prison sections in huge numbers. They wreak havoc in the prisoners' rooms, confiscating their personal belongings and electric appliances to provoke them into a problem and; consequently, suppress and attack them. The Prison Services transfer prisoners to other prisons ${ }^{35}$, isolate them from the outside world and prevent the visit of parents and lawyers; they also ban newspapers and news.

Meanwhile, the prison administration conducts some dialogues with the leaders of the strike in order to reach an agreement, because the continuation of the strike

\footnotetext{
${ }^{32}$ The National Committee for Mobilization and Guidance consists of members with long and huge experience, expertise and knowledge about strikes and prison life in addition to members with good knowledge of medical issues.

${ }^{33}$ Jaber, H. (2016): Al-Aseer (The Captive). Nablus: People's

Library, Palestine. Pages 98, 99.

${ }^{34}$ Ibid page 99.

${ }^{35}$ Ibid pages 104, 105 and 107.
}

means igniting the Palestinian street and wasting a lot of money to treat the hunger strikers ${ }^{36}$.

\section{The World of Prison and the Jailor}

Friehat (2000) postulates that the theme of prisons, torture and absence of freedom is part of the discourse of the Arab novel. Many Arab novelists have come up with this idea in their novels, making prison descriptions and the colors of torture and humiliation both enjoyable and disturbing ${ }^{37}$.

In the Palestinian literature, the narrative writing inside the occupation prisons has been affected by the tragic situation of the Palestinian prisoner. The issues of arrest, interrogation, the living conditions of the prisoner inside the prison rooms and cells and the prisoner's humiliation at the hands of the prison service are among the most important topics dealt with in the novel specially because the author himself is a prisoner.

\section{Arrest and Torture in Interrogation Centers and Detention Camps}

The story of the prisoner has many images about the brutal practices of the Israeli occupation authorities during the arrests of prisoners and the torture and humiliation at interrogation centers. Like other Palestinian stories, novels, or accounts that dealt with this theme ${ }^{38}$, the main objective of the current novel is to give the reader a clear picture of what the prisoner is exposed to and suffer from and to disclose and cover the ugly face of the Israeli Occupation that does not have the least humanitarian value in dealing with the Palestinian people (Al-Hodaly, 2003). We recognize these images and practices through what the narrator and the protagonist say about his detention experience, which is similar to that of other Palestinian prisoners.

Since its inception, the arrest of Palestinians has witnessed flagrant violations of human rights. It normally begins by monitoring the movement of the captive and besieging his/her home with large troops of heavily armed soldiers. They enter his house as wildly as rabid dogs, snatching him from the bosom of his family without allowing them to say goodbye ${ }^{39}$. They tie his hands back with a plastic thread, blindfold him and throw him on the floor of a military vehicle that leaves quickly.

\footnotetext{
${ }^{36}$ Ibid page 108.

${ }^{37}$ See, Freihat, A. (2000): Maraya Ar-Riwaya Al-Arabiya (Mirrors of Arabic Novel). Damascus: Arab Writers Union, Syria.

${ }^{38}$ For more details about forms of torture inside jails and prisons look at, Munif, A. (2001): East of the Mediterranean; Khouri, E. (2002): Yallo; and Odeh, A. (2005): Dreaming of Freedom.

${ }^{39}$ Jaber, H. (2016): Al-Aseer (The Captive). Nablus: People's Library, Palestine. Pages 12, 13.
} 
As the narrative proceeds, we learn more of the brutal practices of the enemy. When the prisoner reaches the designated place, the soldiers beat him and curse him blindfolded. At the center of the investigation, the prison doctor participates in the humiliation the prisoner before recording information about his or her health or illnesses. In a closed yard, Israeli soldiers gather the prisoners half-naked except from their underwear, waiting to enter a room where a personnel information officer records information and the objects in their possession. Then each prisoner is given a number instead of his name and is forced to wear pants and a shirt from a pile of clothes lying in the corner of the room without allowing him to choose what fits his size.

Through the story of the protagonist of the novel and from his position in the heart of the event, we recognize the various types of psychological and physical torture that the prisoner is subjected to in the interrogation rooms including beating, isolation in solitary cell, the presence of a ghost on the chair accompanied by loud music for days ${ }^{40}$, a stinky smelling sack covers his head, the involvement of more than one investigator/interrogator to extract information from him $^{41}$, in addition to threatening to bring his mother or fiancée to prison to force him to confess ${ }^{42}$.

\section{The Prison, its Chambers and Its Cells}

The prison has always been an incentive to writers in the sense that it is completely different from the real world outside the confinements of these jails. These writers normally start, through imagination, to express their impressions and attitudes about prison life in such a way that enables the readership to identify the lexical meanings and connotations of prison life. Once the prisoner enters the jail, his journey of torture and sufferings start. This journey normally ends when he is released. However, the dire consequences or impacts never end.

Haytham Jaber and his protagonist give us a complete descriptive picture of the prison, which enables the reader to imagine the place where the Palestinian prisoner lives and to learn about his details ${ }^{43}$. The nature of prison buildings is part of the policy of restrictions and psychological warfare practiced by the occupier against the Palestinian prisoners; this is shown through the precise description of the prison rooms and cells and their impact on the behavior of the personality, its actions and the development of psychology as well as decision making. In the cell which is no more than two

\footnotetext{
${ }^{40}$ Ibid page 15 .

${ }^{41}$ Ibid pages 14,17 .

${ }^{42}$ Ibid page 30 .

${ }^{43}$ Many captive narrators and novelists (e.g., Mansour, E. (2011) in his novel "Prison of the prison" and Fataftah, H. (2012) in his novel "The Autumn of waiting") have described the cells and rooms of jails.
}

and a half meters long, smells of impurity prevail and suggest the atmosphere of graves and depression. There is a mattress lying on the ground; it is very thin and, above all, it stinks. The atmosphere there is very gloomy and displays or suggests death ${ }^{44}$. The protagonist says " I'm the prisoner here staying within this dirty time lying underneath the salty walls of the cell. I practice my convictions rather than the convictions of the other, the jailor, in the open space. I dream of sleeping easily and comfortably; I long for a short nap peacefully on a slim, thin mattress although other sleep in warm beds. I don't complain and I'm satisfied. If I'm given the chance to choose my destiny again, I'll choose the same route. I never got tired and I'll never ${ }^{45}$."

The prisoner collects the cigarette butts and kneads them with water; he entertains himself by writing whatever he thinks of on the walls until he becomes tired and feels his triumph over the harshness of the place and its filth ${ }^{46}$. When he goes out to the other prison rooms, this is half release for him because there he can see people and eat and go to the bathroom whenever he wants, albeit relatively. However, the prison room is similar to the cell in terms of narrowness. The bathroom is part of the room with five beds, above each other, intended for ten prisoners coming from all over Palestine and the diaspora, besides a wall mounted TV and an electric cooker for preparing food.

The place/prison is not confined to the prisoner's body and his psychological state, but extends to the language of his body which is depleted as is the case of his body, which is weakened and exhausted inside the walls of the prison that oppress men and prey on their life. "Sometimes a prisoner walks with another prisoner and does not find what they say, not even a single word during the whole break as where the letters and language are limited inside the prison ${ }^{47}$. The enforced exile in which the prisoners live for years makes results in forgetting and exhausting their speeches which cannot be renewed unless there is a new prisoner. The effect of the place also extends to the sense of time. "In prison, the clock stops rotating and time is a pressure and weight factor on the prisoner who feels the time overlap in the no-time ${ }^{48}$. Both time and jailor control everything related to prisoners' life. The walls and bars of the cells consume and eat their time and grief overtakes his heart ${ }^{49}$ ".

\section{Inspections, Breaks and Counting}

The place of the novel holds the events and its characters and leaves it only a limited margin of freedom of movement. In prison, the daily count is imposed on

\footnotetext{
${ }^{44}$ Jaber, H. (2016): Al-Aseer (The Captive). Nablus: People's Library, Palestine. Page 26.

${ }^{45}$ Ibid page 28 .

${ }^{46}$ Ibid page 40 .

${ }^{47}$ Ibid page 113 .

${ }^{48}$ Ibid page 91.

${ }^{49}$ Ibid page 146.
} 
the prisoners in the early morning and at night prison facilities are closed. The movement is prohibited outside the rooms at 6:00 or 7:00 pm when the prisoners who are serving in the kitchen come back to their rooms ${ }^{50}$. During breaks, the prisoners are allowed to go the courtyard ${ }^{51}$ to walk and to be exposed to the sun. The place imposes its rituals on them and their movements are colored just like it; they walk in circles- like a person circumambulating the Kaaba- so that they do not crash with each other ${ }^{52}$.

As the story goes on, the writer tells us what his hero tells us about the details of the inspections and searches and how the prison officers break into the prisoners' rooms with their full kit and equipment to torture them and make them think only about the reality of bars, oppression and deprivation. Each group of soldiers stands in front of a cell door or a room, closes the door and binds the prisoners and takes them out, individually, to the courtyard. During the inspection process, a representative of the prisoners is brought up to witness everything and make sure that nobody tamper with their belongings or sabotage them. However, the soldiers mix and sabotage everything, confiscate their books, pamphlets and other stationery they use to educate their followers and members about each organization to identify its ideology and political ambitions. "There is nothing wrong with the Israelis even torture which is practiced in scientifically ${ }^{53}$."

In cases of prisoners' rebellion, the prison administration calls for more repression brigades or military units, stuffed with tear gas, batons, sound bombs and rubber bullets. They besiege and surround the prisoners' rooms and cut off water and electricity supplies so that the prisoners would not use water or hot oil as a weapon against the jailor. When things get worse, the soldier throw sound and gas bombs inside the sections and spray the prisoners with tear gas ${ }^{54}$. After making sure that the captives are in a fainting situation, they are forced into their rooms, handcuffed and taken to the break square. The soldiers beat them fiercefully and force them to sit for hours in a squatting manner.

\section{In the Court}

The trial of the prisoner and his transfer to the court more than once is a kind of torture and humiliation practiced by the military occupation against the prisoners to break their will and keep them from returning to the fields of jihad and struggle after their release.

In Haytham Jaber's novel, the narrator focuses on describing the prisoner's journey to court to take the

\footnotetext{
${ }^{50}$ Ibid page 52.

${ }^{51}$ The courtyard of the prison is a small yard in which prisoners are set free to get fresh air and get exposed to sun.

${ }^{52}$ Jaber, H. (2016): Al-Aseer (The Captive). Nablus: People's

Library, Palestine. Page 156.

${ }^{53}$ Ibid page 159 .

${ }^{54}$ Ibid page 166.
}

readership into the occupation courts and airspace and to inform him of the psychological and physical suffering of the prisoner on his journey to it. The journey begins with waiting for the prisoner to get to prison bus ${ }^{55}$ together with criminal Jewish prisoners; the Palestinian prisoners are deprived of food and they are constantly beaten and insulted while traveling. And to exhaust the prisoner psychologically and physically, the journey, which does not need more than an hour or two, takes a full week transferring them from prison to another, eventually bringing them to Ramla Checkpoint, their last stop $^{56}$. In the court, which is run by three military judges, the prisoner is brought, full of dignity and pride despite oppression and suffering, handcuffed and footed and surrounded by a number of guards; however, the judges adjourn the trial or read the verdict that was prepared in advance. The prisoners know that these trials are mere plays prepared and directed by the judge and the opponent himself who is the same person. "Here there is no defense nor witnesses or lawyers ${ }^{57}$."

\section{The Visit}

When prisoners' families visit their relatives, joy and sorrow meet together. On the one hand, the prisoner meets with his family after a long period of time. On the other hand, the visit is arranged by the jailor and according to his agenda, arrangements and, above all, policy. Many novelists have focused a lot on this scene when prisoners meet their families ${ }^{58}$.

"The Captive" portrays, via demonstrative realistic description and narration, a fine picture of the journey of torture and suffering during the visit. The writer tells the readership about the finest things of these visits starting with the times, place, routes and even numbers of relatives, let alone the role of the Red Cross. He also give a good account of the strong feelings of love and longing for the family to their children and relatives. This is clear in the experience of one of the prisoners narrated to another by the protagonist of the novel who says "His turn was during the second round; he headed for the meeting hall where each prisoner is pushed to a window which shows his family. Once he got there, he started waving. He approached the fence and gave each one a kiss from behind the window. They wished they could hug him ${ }^{59}$."

\section{The Jailor}

The narration about the jailor who represents the occupier irrespective of his many different names in the

\footnotetext{
${ }^{55}$ Prison bus is the bus which is responsible for transferring prisoners from one jail into another.

${ }^{56}$ Ibid page 172 .

${ }^{57}$ Ibid page 173 .

${ }^{58}$ Ibid page 173 .

${ }^{59}$ Ibid page 77.
} 
novel is a crucial part; we learn about his image through what the prisoner tells when he talks about his experience in prison and the torture and humiliation he suffers $^{60}$ at the hand of the soldiers whose image is not different from the other image drawn by many other Palestinian narratives specifically those written by Islamic thinkers or novelists. "They are the occupants of the human race; they are savage bastards and arrogant murderers; their history is stained with blood; they built their state of tyranny and mutilated entity on the skulls of their victims. Their soldiers are like the wolves of the night and their military barriers are cutting off the nation and splitting the people ${ }^{61}$; their media is part of the machine of oppression and deception that exercise all forms of lying by the Zionist lobby."

The image of the interrogator looks ugly; he is a huge creature with a bald head and a reversed nose. Smells of hatred and criminality prevail the place; he manipulates and tries all arts of torture to harm and humiliate the prisoners physically and psychologically (Al-Hodaly, 2016). The majority of Palestinian novels ${ }^{62}$ have drawn almost the same image. The judges of the courts are no different from the others; they are criminal soldiers, opponents and judges alike ${ }^{63}$.

The jailor is like the others who practice repression and torture against the captives. He is the most important part of the Israeli machine of oppression, torture and humiliation. He has a yellow smile that is full of blasphemy ${ }^{64}$. He constantly attacks the Palestinian prisoners to deprive them of their rights and make them in a state of tension, anxiety and self-defense. A sadist scourger and whipper who is fond of harassing others; he is so coward that he does not break into their rooms until they have been sprayed with tear gas, making sure they are all in a state of fainting. He cuffs the prisoner who is on hunger strike and unable to stand ${ }^{65}$.

\section{Conclusion}

The story of Haitham Jaber appeared as if it is a documentary that is far from illusion and fantasy. The

\footnotetext{
${ }^{60}$ For more details about the image of the jailor in Palestinian prison novels see Al-Natsheh, J. I. J. (2016): The Palestinian captive as a narrator. Unpublished doctoral dissertation. Jordan University, Amman, Jordan, pages 31-40.

${ }^{61}$ Jaber, H. (2016): Al-Aseer (The Captive). Nablus: People's Library, Palestine. Page 178.

${ }^{62}$ For more details about the image of Jews look at Walid AlHodali novel; and Abu Hanish, A. (2016) "The Image of the Jew and the Image of the Arab in Models of Arab Novel at the beginning of the twenty first Century". unpublished doctoral dissertation. Jordan University, Amman, Jordan, pages 121-127.

${ }^{63}$ Jaber, H. (2016):. Al-Aseer (The Captive). Nablus: People's Library, Palestine. Page 81.

${ }^{64}$ Ibid page 173.

${ }^{65}$ Ibid page 92 .
}

author, who was a prisoner himself, was arrested and then tortured severely by the Israeli jailor. He has depicted, in a technical and vivid way, the various aspects of the lives of the Palestinian people under occupation, they ways they are arrested and tortured, the prison rooms and cells and their psychologically and physically impact on the prisoner, the prisoners' society inside the prison and their way of managing their daily lives. ..). The novel is a kind of real evidence and witnesses the practices of the occupation and its arrogance and the way it deals with Palestinian prisoners within the confinements of its prisons and detention centers.

The story provided detailed information about the struggle of the captive movement inside the prisons of the occupation from the beginning until the time of writing the novel, as well as detailed information about the various means of repression practiced by the prisoner against the prisoners to thwart their strikes and undermine their steadfastness. Furthermore, the story shows a bright picture of the experience of the Palestinian prisoners of democracy to exchange power within the prison and the way they manage their political, organizational and struggle affairs inside the prison.

The novel stressed that the aim of the struggle of the captive movement within the prisons of the occupation is to achieve the minimum elements of life at the level of living (allowing brushes into the rooms, removing metal panels that cover windows and block the sun, allowing books and stationery and, at the political level, (recognizing them as prisoners of war, demanding their release ...).

The novel showed a complete descriptive picture of the occupation prisons, enabling the reader to imagine the place where the Palestinian prisoner lived and to know the details. The place seemed part of the policy of restraint and psychological warfare practiced by the occupier prisoners in prisons, which is reflected on their daily psychological and physical life.

The image of the prisoner who represents the occupier in the novel (the soldier, the interrogation officer, the prison guard, the prison doctor, the judges of the courts ...) is a repulsive ugliness that is not very different from his image in many Palestinian accounts. All of them are occupied despots who are used to practicing various forms of oppression, torture and humiliation against the Palestinian prisoner to keep him away from the fields of struggle.

The novel, along with other accounts written by the prisoners in Israeli jails, is a living proof of the failure of the occupation policy to isolate the Palestinian prisoners and deprive them of their ideology and struggle. The Israeli prisons have been turned into schools that teach the Palestinians not only sciences but also culture and struggle. Within the prisons, the educated members of political organizations and factions supervise the preparation and implementation of educational and cultural programs for prisoners. 
The novel "The Prisoner" is significant enough despite the weakness of its linguistic structures and complexity and the large number of spelling and typographical errors. It is an important addition to the prison literature due to the detailed information, it provides, about the lives of Palestinian prisoners in Israeli jails.

\section{Acknowledgement}

It is a pleasure of mine to thank my family for their support all through this research. They have been of a great help all my life. Moreover, I would like to express my appreciation to my friends and colleagues for their advices on this subject matter.

\section{Ethics}

The article was transalted from Arabic into English. It analyzed Haytham Jaber's novel "The Captive." This novel focused on Palestinian prisoners' lives in the Israeli jails. The author understands that this is a throny issue. Some may agree with what was written in the article; others may disagree. The research was written soley for scientific purposes, and should be taken as such. However, some may not take the terms and phrases used here. But, as it has been mentioned above, the author did her utmost to be objective all through the research.

\section{References}

Abdullah, H., 1994. An-Nitajat Al-Adabiya AlI'ietiqaliya: Dirasah Tarikhiya Tahliliya [Captivity Literary Products: A Historical-Analytical Study], Jerusalem: Al-Zahra'a Studies and Research Centre, Palestine.

Abu Al-Haaj, M., 2016. At-Tajriba Ad-Dimoqratiya LelAsra Al-Falestinineen fi Al- Muataqlat Al-Israeliya 1967-2007 (The Democratic Experience of Palestinian Prisoners in Israeli Jails 1967-2007). AlQuds University: Abu Jihad Centre for Prisoners' Affairs, Palestine.

Abu Hanish, A., 2016: The image of the Jew and the Arab in some Arabic novels at the beginning of the twenty-first century. Unpublished doctoral dissertation, Jordan University, Amman, Jordan.

Abu Hanish, K., (N.D.): Bashaer [Good Tidings]. Ramallah: Palestinian National Committee for Education, Cultureand Sciences, Palestine.

Abu Hanish, K., 2017. Alam Bela Qarar [Endless Pain]. Nablus: People's Library, Palestine.
Al-Hodaly, W., 2003. Sataer Al-Atmah: Tisoun Yawman fi Zanazeen As-Sojoun Al- Israeliya [Curtains of Darkness: Ninety Days in Israeli Prison Cells]. Ramallah: Palestine Institution for National Guidance, Palestine.

Al-Karmi, A., 1971. Min Filastin Rishati [From Palestine is My Brush]. Beirut: Dar Al-Adaab, Lebanon.

Al-Natsheh, J.I.J. 2016. The Palestinian Captive as a Narrator. Unpublished doctoral dissertation. Jordan University, Amman, Jordan.

Fataftah, H., 2012. Khareef al-Intithar [The Autumn of Waiting]. Ramallah: Ministry of Culture, Palestine.

Freihat, A., 2000. Maraya Ar-Riwaya Al-Arabiya [Mirrors of Arabic Novel]. Damscus: Arab Writers Union, Syria.

Jaber, H., 2016. Al-Aseer [The Captive]. Nablus: The People's Library, Palestine.

Khandakji, B., 2014. Misk Al-Kifaya: Sirat Sayetedd Althilal Al-Hura [The Good Ending]. Beirut: Arab Scientifc Publishers, Lebanon.

Khouri, E., 2002. Yallo. Beirut: Dar Al-Adaab, Lebanon.

Madi, S., 2008. Anmat Al Rewaya Al Arabeya Al Jadeedah [Modern Types of Arabic Novel]. Kuwait: Alam A-Marefah, Kuwait.

Mansour, E., 2011. Sejen al Sejen [Prison of the Prison]. Ramallah: Ministry of Culture, Palestine.

Munif, A., 2001. Sharq al Mutawaset [East of the Mediterranean]. Bierut: Al-Muasasah Al-Arabiah for Studies and Publications, Lebanon.

Odeh, A., 2005. Ahlam Bil-Huriya [Dreaming of Freedom]. Beirut: Arab Institute for Research and Publishing, Lebanon.

Odeh, A., 2012. Thaman Lesh-Shams [For the Sake of the Sun]. Ramallah: Palestine Democracy Center, Palestine.

Salhout, J., 2012. Adab Al-Sojoun[(Prison Literature]. Jerusalem: Dar Al-Jundi, Palsstine.

Shukri, G., 1970. Adab Al-Muqawamah [Resistance Literature]. Cairo: Dar Al-Maarif, Egypt.

Taha, M., 2010. Raml Al-Afaa -Sirat Ktsiot- Or Ansar 3 [The Snake's Sand-Memoirs of Katsiot, Ansar 3 Detention Camp. Cairo: General Organization of Culture Palaces, Egypt.

Ziyaad, M., 2006. Al-Adab Al-Filistini fi Sojoun AlIhtilal 1987-2002 [Palestinian Literature in the Israeli Prinons] (Literature produced by Palestinian Prisoners in Israeli Jails 1987-2002). Unpublished master's thesis, Beir Zeit University, Beir Zeit, Palestine. 